\title{
Wh-questions in Spanish: Meanings and Configuration Variability ${ }^{*}$
}

\author{
Juan Manuel Sosa \\ Simon Fraser University. Linguistics Department \\ Burnaby B.C. V5A 1S6 Canada \\ sosa@sfu.ca
}

\begin{abstract}
This paper describes the distinct tonal configurations of wh-questions in Spanish and discusses their possible correlations with pragmatic and interactional meanings. The data consisted of both read and spontaneous speech from four Latin American varieties. Two of the dialects, Mexican and Colombian, as opposed to Venezuelan and Puerto Rican, showed a marked preference for rising contours in read speech, while in interviews virtually no such contours occurred for any of the speakers. A different kind of rising contour did regularly occur in the natural speech data, a globally rising contour without a dip before the final high rise, used for confirmation or reprise whquestions. The conclusion of this study is that the unmarked configuration is indeed the gradually descending one, as described in the literature. This applies to all the dialects here examined, in spite of the variability of the contours, which is context-induced and related to information structure.
\end{abstract}

Key words: prosody, intonation, meaning, information structure, wh-questions, tonal configurations, contour variability, Latin American Spanish.

\section{Introduction}

Wh-questions in Spanish are notorious for their intonational variability. This variability is a consequence of both the different kinds of pragmatic functions they serve in natural discourse as well as the reported dialectal differences in the configurations of the unmarked forms. Most traditional studies concerned with Spanish intonation, like Navarro Tomás (1968) and Quilis (1993), have agreed that the melodic design of these questions generally corresponds with the declarative one, with the highest pitch corresponding with the first accented word, after which there is a gradual descent culminating in a final fall. Since in Spanish the wh-word is normally at the beginning of the utterance, the highest peak of the utterance is usually associated with it. For this reason the body of wh-questions with more than 
one pitch accent will tend to have a descending pattern toward the intonational nucleus after this initial peak linked with the fronted wh-word, also called the locus of interrogation. The purpose of the question is concentrated on the wh-word since what is asked is that particular circumstance this initial word refers to.

Regardless of the dialects concerned and the specific functions of wh-questions, their intonational variability is usually centered in the direction of the final contour and the nature of the nuclear tones. Unless the utterance is made up of just the wh-word, in which case the contour will be that of the corresponding nuclear tones (without the characteristic initial rise), the shape of the unmarked Spanish wh-question will be that of a slide, with a sharp initial rise associated with the whword, followed by a gradual descent to the bottom of the speaker's range, after which it may or may not rise again, depending on whether or not it if followed by a high boundary tone.

The purpose of this paper is to investigate the shape and possible final contours of wh-questions according to their pragmatic meaning and their information structure, in four distinct dialects of Latin American Spanish that have been reported as having systematically different intonational structure for this sentence-type: Mexican, Colombian, Puerto Rican and Venezuelan. A main concern is to try to establish if the distinct configurations of wh-questions described in the literature are real dialectal differences, as is certainly the case for yes/no questions (Sosa 1999), or if the fact that they have been described as structurally different, at least from Castilian, may be because the meanings and implications of several utterances in the data were in fact not equivalent or comparable. The main issues discussed here will then be the direction and range of the final nuclear tone, the kinds of overall shapes of the utterances, and the possible correlations between tonal configuration and pragmatic meanings.

\section{The meaning of wh-questions}

From a semantic perspective, the meaning of wh-questions is defined as the set of their contextually possible answers. Thus, as explained in Hedberg and Sosa (2002), a wh-question such as (1a) would have as its semantic value the denotation in (1b), assuming that the set $\{$ José, Jordi, Eulalia\} is the pragmatically restricted set of entities under consideration.

(a) Who saw Teresa?

(b) \{José saw Teresa, Jordi saw Teresa, Eulalia saw Teresa $\}$

In terms of their pragmatic functions, the situation with wh-questions is more complicated. Although the locus of interrogation is the wh-word, which should then be considered the focal element, different kinds of articulation of the information structure, interactional effects and emphasis have an effect in the configuration of the intonational nucleus. The issue here is to determine to what extent the distinct configurations associated with wh-questions in Spanish correlate with different meanings or uses. 


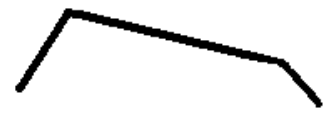

1

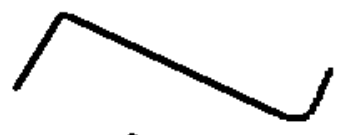

2

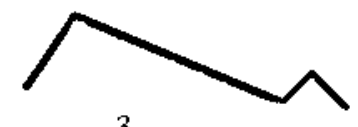

3

Figure 1. The configurations of wh-questions in Spanish according to Navarro Tomás (1968: 229).

In his classic studies of the intonation of Castilian Spanish, Navarro Tomás $(1944,1968)$ distinguished three distinct configurations for wh-questions, in his terminology referred to as 'pronominal' questions. These were: (1) the unmarked falling contour finishing at the bottom of the speakers range; (2) the 'softened' or 'polite' contour, that ends with a rise after an initial descent from the pitch of the wh-word; (3) the 'circumflex' contour, which has a rising-falling pattern after the initial descent. In Figure 1 the three configurations are reproduced.

The interesting issue about these three possibilities is that they are not pragmatically the same, or at least their implications and use are not equivalent. For all three contours the highest pitch is linked to the wh-word.

The first configuration, the unmarked one, is the one normally used when the expected answer is the instantiation of the variable represented by the wh-item of the question. For instance, in the question ¿Quién ha venido? 'Who has come?' it is understood that the speaker is aware that somebody has come and that what she/he wants to find out is precisely who has come. According to Navarro Tomás (1968), such a question indicates as well that the person to whom the question is addressed should know whether or not somebody has come. At the same time, the question has some implication of urgency and that the addressee is under certain obligation to know the matter that is asked and to answer the question. Hence, it is the contour used when the speaker has some authority over the addressee, or between equals in informal situations.

The second shape, the 'polite' one, is used in situations in which the unequal power relations between the speakers, or their lack of solidarity or familiarity would make it inadequate to use the unmarked wh-question. The rising terminal inflexion weakens and attenuates the affirmative base of the question, thus implying some insecurity over the possible truth of what is asked. If the same question ¿Quién ha venido? is uttered with such a contour, then the interest in knowing who could have come leaves open the possibility that in fact nobody has. It also leaves a wider range of answers to the possible reply and is less compelling than the falling whquestion.

The third shape, the rising-falling 'circumflex' one, is characteristic of a question that also expresses amazement or surprise about the very fact that whatever is being asked can have taken place. The final rise-fall adds extra emphasis to the word bearing the nuclear tone, an effect also associated with narrow focus. It somehow conveys exclamation or involvement in the situation, with more implication of urgency and assertion than the wh-question without this peak. From Navarro's 
account of the variants it follows that the three configurations are not interchangeable or in free variation since they are situational and context-dependent.

Quilis (1993) also distinguishes between the unmarked falling wh-question (enunciado interrogativo pronominal) and the 'polite' one with rising ending (pregunta pronominal con matiz de cortesía), in the same terms that Navarro Tomás describes these contours for Castilian Spanish, both in their shape and their use.

In addition to these, Quilis includes three more pragmatically-conditioned configurational possibilities for wh-questions: the emphatic wh-question (pregunta pronominal enfática), the reiterative question (pregunta reiterativa) and the exclamatory wh-question. These supplementary kinds of wh-questions also differ in their pragmatic meanings according to the speakers and the situation. However, in Quilis' description the intonational difference between these three 'expressive' kinds of utterance seems to be quite small, so much so in fact that he proposes the same kind of 'level analysis' for all three, as follows:

$\begin{array}{llllll}1 & 3 & 2 & 1 & 2 & 1\end{array}$

/poR ké nó me lo dí日es $\downarrow /$ ¿Por qué no me lo dices? (Emphatic wh-question, p. 448)

$\begin{array}{llllll}1 & 3 & 2 & 1 & 2 & 1\end{array}$

/ke poR ké nó me lo dí日es $\downarrow /$ ¿Que por qué no me lo dices? (Reiterative question, p. 450)

$\begin{array}{llll}3 & 2 & 12 & 1\end{array}$

/ké bás a a $\theta \mathrm{eR} \downarrow /$ ¿Qué vas a hacer? (Exclamation, p.453)

Notice that in all three examples the level assigned to the wh-word Qué is the level 3, and that starting with it, the rest of the utterances in the three cases are identical ${ }^{1}$. The only difference between these 'expressive' wh-questions and the unmarked ones, according to the notation used by Quilis, is the relative pitch height of the interrogative word, which is higher in the former than in the latter. The examples that follow are the level representations of the same utterances in their nonemphatic pronunciations:

\section{$\begin{array}{llllll}1 & 2 & 2 & 1 & 2 & 1\end{array}$}

/poR ké nó me lo dí日es $\downarrow /$ ¿Por qué no me lo dices? (Unmarked wh-question, p. 432)

22121

/ké bás a a $\theta \mathrm{eR} \downarrow /$ ¿Qué vas a hacer? (Unmarked wh-question, p. 432)

1. Although Quilis assigns the exact same level analysis to all three contours, there are clear configurational differences between these utterances in the graphs of the fundamental frequency that accompany them: in the emphatic wh-question (example [42], p. 448), the first unstressed word por is much higher than the same word in the reiterative question (example [48], p. 450). In spite of this noticeable difference they are given the same level 1 in both cases. There is in Quilis' account a number of other cases in which the tonal level assigned to the different words do not seem to correspond to the actual F0 trajectory as shown. 
It is obvious then according to Quilis (1993), that the tonal feature that distinguishes the 'expressive' from the unmarked wh-questions is exclusively the increased height associated with the wh-word in the expressive ones, as if upstepped. These may be gradient phenomena affecting pitch range, so for many autosegmental-metrical approaches this difference would not be considered truly phonological.

The difference in meaning between these normal, unmarked wh-questions and the marked (polite, reiterative, emphatic and exclamatory) appears to be situational and interactional, that has to do with the dialogue dynamics between the speaker and the hearer, not in the truth conditional or propositional meaning of the sentences. The marked ones do not suggest either, of the myriad possible replies to a wh-question, which kinds of responses would be more likely than others.

Now, although not explicitly mentioned or described as a distinct and meaningful intonational shape for wh-questions in the literature on Spanish wh-questions, in my data there is another type of utterance configuration that is quite common, the higher rising one. It is mostly used as a confirmation or reprise question and differs configurationally from the rising 'polite' of Navarro and Quilis in that the rise happens throughout the utterance, not after a descent on the nuclear tone. Also, the highest peak does not normally associate with the wh-word.

In order to establish the actual uses and implications of the attested variants, it is necessary to study these wh-questions as they occur in natural speech, thus taking into consideration the context. Questionnaires are also useful in order to elicit «out of the blue» utterances in order to test the hypothesis that the unmarked forms of wh-questions vary in different dialects.

\section{Data and methods}

For this research I used both a questionnaire and natural speech (sociolinguistic interviews). The questionnaire consisted of a list of sixteen wh-questions ${ }^{2}$ taken from the chapter on wh-questions in Spanish of La Pronunciación del español. Curso prácti-

2. The questions on the questionnaire were:

1. ¿Cuándo oúste la noticia?

2. ¿Dónde está Miguel?

3. ¿De qué viven los artistas?

4. ¿Cuándo vienes a visitarme?

5. ¿Qué diablos hace usted aquí?

6. ¿Con quién llegó a la fiesta?

7. ¿Por quién doblan las campanas?

8. ¿Por qué miras así?

9. ¿Cómo cocinaste el pollo?

10. ¿De dónde son los cantantes?

11. ¿Cuán grande es tu amor?

12. ¿De qué está hecho el techo?

13. ¿ Adónde fueron los niños?

14. ¿Para qué sirve ésto?

15. ¿Cuánto te debo?

16. ¿Quién da más? 
co, the textbook of a video course on Spanish phonetics intended for students of Spanish as a second language, authored by D'Introno and Sosa (1986:83). The subjects were instructed to read the questions on the list in a natural way, that is, they were requested to ask those questions to the interviewer as in a real dialogue.

For the read part of the data I used the following six informants, all with university degrees and in their early thirties: a male and a female from Mexico City; a male and a female from Bogotá, Colombia; a female from San Juan, Puerto Rico; and a male from Caracas, Venezuela.

The recorded interviews of spontaneous conversation lasted some 45 minutes each, and took place between the informant and one interviewer. The four participants were not the same speakers that took part in the questionnaire. The informants selected were a male from Mexico City, 18 years old; a female from Bogotá, 45 years old; a female from San Juan, 36 years old; and a female from Maracaibo, Venezuela, 23 years old.

All the wh-questions of the interviews were digitized using the Computerized Speech Lab 4300, and the pitch tracks were obtained using Pitchworks Version 5.0. The utterances were analysed in terms of their overall shape and relative pitch height, the kinds of tones associated with the wh-words and the direction of the final contour.

\section{Rising and falling contours}

Intonationally, the most obvious distinguishing feature between types of wh-questions is whether they end with a falling or a rising contour. This is the primary standard of judgment I have used in order to classify the utterances, although it has been necessary for the sake of precision to distinguish between two types of falling and two types of rising configurations. As seen in Navarro's diagrams, there are at least two types of falling wh-questions in Spanish, the unmarked one that gradually descends to the baseline after the initial rise associated with the wh-word, and the more emphatic and exclamative one, the rising-falling 'circumflex' contour. An example of the most common unmarked falling contour is shown in (1) and in Figure 2. This is a 64 year-old Venezuelan female speaker, asking «out of the blue» ¿Dónde están los niños? 'Where are the children?' The highest frequency corresponds to the wh-word.

\section{¿Dónde están los niños?}

An example of the emphatic contour is shown in (2) and in Figure 3. The context is the following: The interviewer is a twenty year old female, native speaker of Spanish of Chinese ancestry. The informant, the forty-five year old woman from Colombia, is puzzled by this fact and asks the interviewer about her family, ending with an exclamative wh-question about the fact that an Asian woman is speaking Spanish and asking questions about Spanish, and asks ¿Cómo una oriental está aquí hablando español y haciendo entrevistas de español? 'How is it that an Oriental girl is here speaking Spanish and conducting interviews in Spanish?'. In this con- 


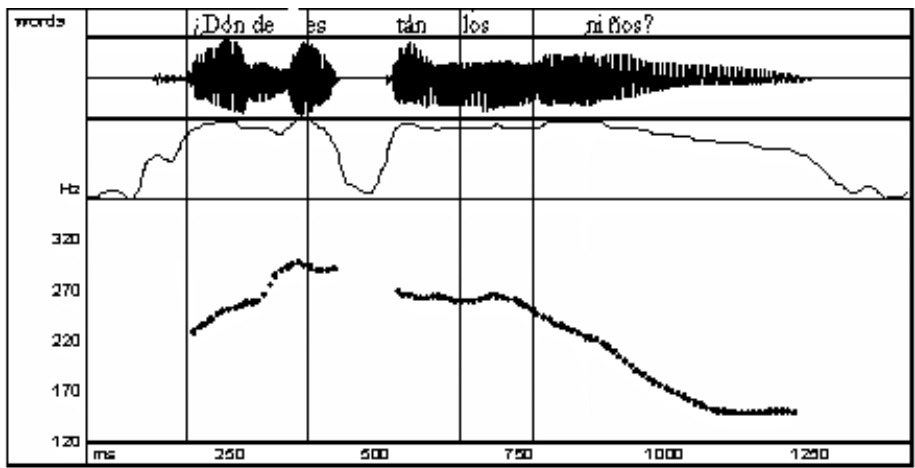

Figure 2. Standard falling contour of an unmarked wh-question, Venezuelan female speaker.

tour, in spite of its length and the fact that it consists of two intonational phrases, the most prominent peak is associated with the initial wh-word Cómo 'how.' Notice also that the final peak is also very prominent, consistent with the kind of final contour associated with focus.

(2) Informant: Cuénteme: ¿Usted viene de familia oriental?

Interviewer: Sí

Informant: Todo me imaginé, yo me imaginé, ¿Cómo una oriental está aquí hablando español [\%] y haciendo entrevistas de español? [laughs] ] 'How is it that an Oriental girl is here speaking Spanish and conducting interviews in Spanish?'.

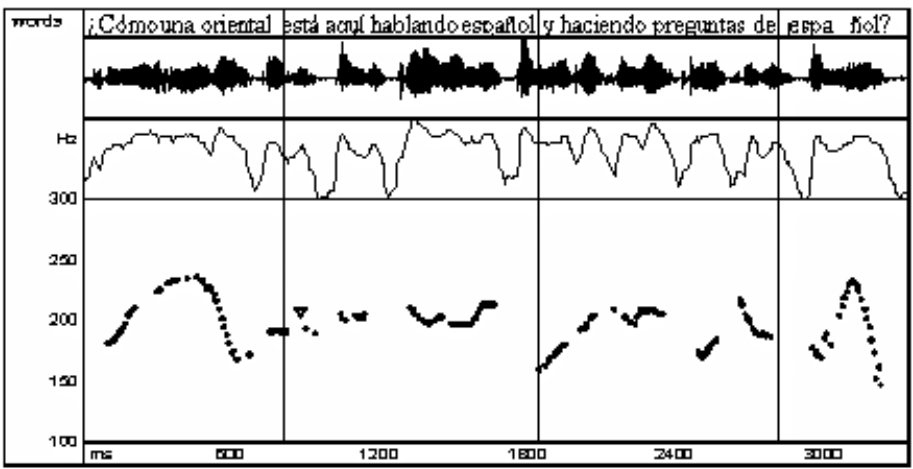

Figure 3. An exclamative wh-question with a final falling-rising final contour, Colombian female speaker. 
Regarding rising contours, there are also at least two types that are distinctive in meaning and configuration: (i) the one described by Navarro, that descends from an initial rise all the way to the bottom of the range before rising again at the end (as in Figures 5 and 6 below); and (ii) the one that has a characteristic ascending trajectory to the end, without going down near the baseline on the intonational nucleus. In (3) we see the context of an example of this continuously rising question, shown in Figure 4. Here the interviewer (the author) interrupts the informant (the young woman from Maracaibo), to tell her to use the familiar vos instead of the polite usted, after which the informant asks the interviewer to remind her of his first name, something equivalent to 'What did you say your name was?'

(3) Informant: ...por alcanzar...

Interviewer: Pero trátame de vos

Informant: Ajá, es... ¿Cómo es que se llama usted?

Interviewer: Juan

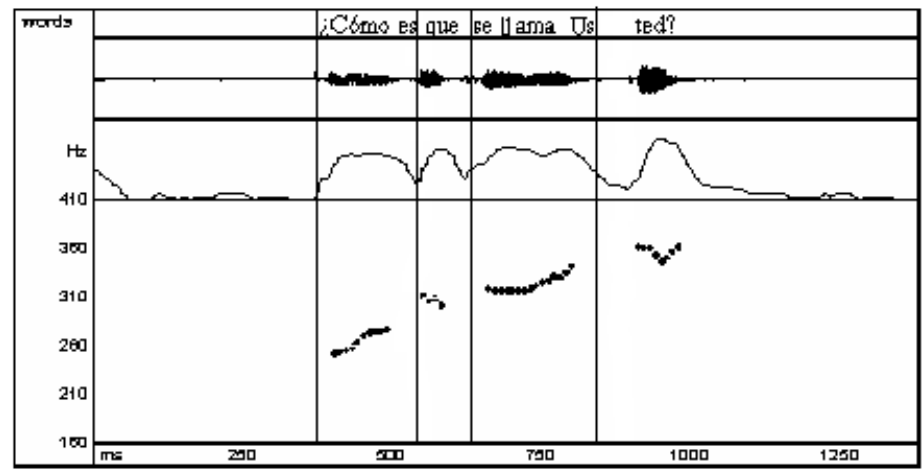

Figure 4. A higher rising contour without a fall in the nucleus, Venezuelan female speaker.

The four types of contour tend not occur in the same contexts since their meaning and communicative implications are not equivalent. Also, they may not used with the same frequency in all the varieties of Spanish, which is one empirical question to be addressed.

\section{Wh-questions in read speech}

For the comparison between the types of configuration of the different dialects, the distinction made was primarily whether the contours were falling or rising. Or, to put it in autosegmental-metrical terms, whether they end with a low or a high boundary tone ( $\mathrm{L} \%$ or $\mathrm{H} \%)$. The results, at least for the questionnaire part, seemed to suggest clear distinctions between the Mexican and Colombian configurations, 
on the one hand, and the Puerto Rican and Venezuelan ones (Caribbean Spanish) on the other, although as we shall see the analysis of the wh-questions occurring in the sociolinguistic interviews suggested otherwise.

The sixteen wh-questions of the questionnaire were produced by the Mexican female informant with a rising contour fourteen times, nearly $88 \%$, which could be considered a good indication that this type of contour is the default shape of whquestions in this dialect. Since these wh-questions were read from a list without any discourse context, and were directed to the interviewer, it is tempting to infer that the rising variant should be the unmarked one. The Colombian female also produced a rising contour for fourteen of the sixteen wh-questions or $88 \%$, so again it could be said that at least for read and context-less wh-questions, the overwhelming tendency is to produce the rising variants. Figure 5 shows a typical response of the Mexican female, a rising contour that conforms to Navarro's description, except that the final rise ends higher than for Castilian. The utterance is number 13 in the questionnaire, ¿Adónde fueron los niños? 'Where did the children go?'

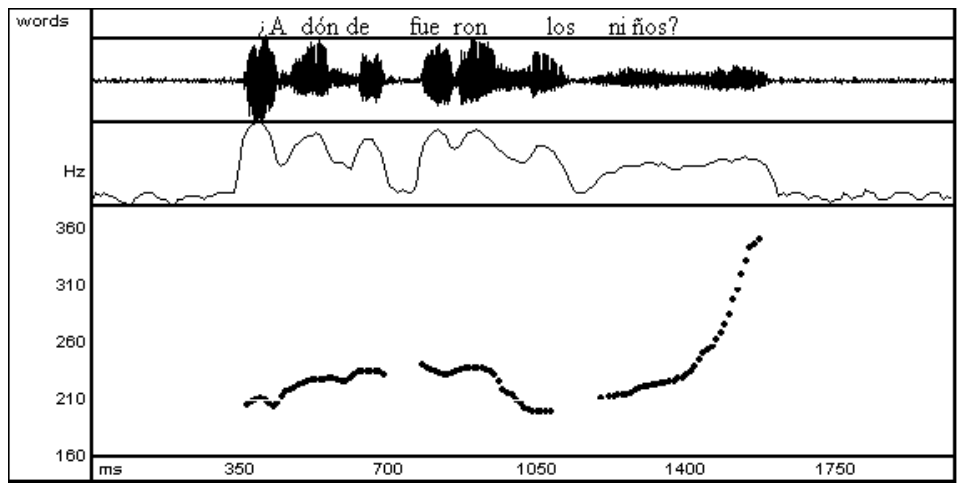

Figure 5. A standard rising wh-question with a fall on the nuclear syllable before the high final rise (Mexican female Speaker).

The Mexican male had eleven rising contours out of sixteen or $69 \%$, which although less than the female informant, is still very meaningful. The Colombian male had ten out of sixteen or $63 \%$, also meaningful. The difference between the females and males of the two dialects, with higher percentage of falling contours for the males, could be interpreted as an effect of the fact that falling contours are more direct and assertive, which has been reported to better suit male styles of speech in general. Interestingly, these rising contours conform to the shape described by Navarro (1968) for the Peninsular variants (shown as number 2 in Figure 1), in fact all of the rising contours derived from the questionnaire were of this type. In Figure 6 a typical rising contour produced by the Colombian male is shown. The utterance is number 15 in the questionnaire, ¿Cuánto te debo? 'How much do I owe you?' 


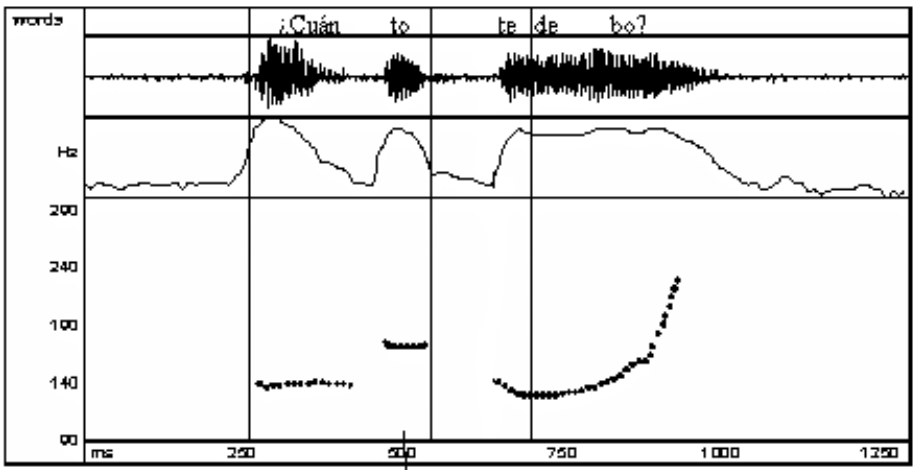

Figure 6. Another example of a contour that rises after a nuclear fall (Colombian male speaker).

The high percentages of use of rising contours for Mexican and Colombian Spanish may be more categorical if we notice that for question 5 of the questionnaire ¿Qué diablos hace usted aquí?, all the informants except the Mexican female had a falling contour, clearly because of the challenging tone implied by the wording of this question (something like 'What the hell are you doing here?'). This observation also applies for question 8 ¿Por qué miras así? 'Why are you looking at me like that?', which all the informants pronounced with a falling pattern, again expressing challenge, reproach. A more neutral wording of this question would presumably elicit a more natural interrogative utterance, which according to the rest of the responses given by the Mexican and Colombian speakers would then be a rising contour. These results seem conclusive enough to report a significant preference toward rising wh-questions in read speech for these two dialects, but certainly not sufficient evidence to postulate it is the unmarked configuration for whquestions.

The Puerto Rican and Venezuelan informants had completely different percentages: the great majority of the contours for them were falling ones, 15 out of $16(94 \%)$ for the Puerto Rican woman and 14 out of $16(88 \%)$ for the Venezuelan man. Again, this looks like good evidence to suggest that falling contours are the norm for this dialects, and thus to conclude, on the basis of these results, that the configuration of unmarked wh-questions are falling in these Caribbean dialects ${ }^{3}$. If true, this would parallel what happens with yes-no questions, that are systematically rising in Mexican and Colombian and falling in Puerto Rican and Venezuelan

3. The wh-questions with final rise for the questionnaire were all of the type illustrated by Navarro in the second contour in Figure 1, as in Figures 5 and 6. The following table summarizes the rising contours by speaker:

\begin{tabular}{llllll} 
Mexican (f) & Mexican (m) & Colombian (f) & Colombian (m) & Puerto Rican (f) & Venezuelan (m) \\
\hline $14 / 16$ & $11 / 16$ & $14 / 16$ & $10 / 16$ & $1 / 16$ & $2 / 16$ \\
\hline
\end{tabular}


(Sosa 1999). Indeed, Sosa had suggested but not proven that some kinds of whquestion configurations are more common in certain dialects than in others, and also that there may be systematic differences for the same kind of pragmatic meaning, between dialects in the same dialectal area., eg, Puerto Rican and Venezuelan unmarked wh-question.

In order to test this hypothesis that the neutral, unmarked wh-questions are rising in some dialects and falling in others, the non-scripted speech data from the interviews was analyzed. The results reported below do not substantiate this claim.

\section{Wh-question configurations in the interviews}

In the sociolinguistic interview of the 18 year old speaker from Mexico City, only falling contours were found. This directly contradicts the findings based on the responses to the questionnaire by the other Mexico City speakers since not a single rising contour was produced. It is thus necessary to conclude that read utterances do not necessarily reflect the actual use of rising versus falling wh-questions in this dialect. The descending contours were all of the type described for the normal wh-questions by Navarro (1968) for this informant, and an example of this contour is shown in (4) and in Figure 7. In this case the young male subject is asking questions to the female interviewer, hesitates and asks her her age ¿Cuántos años tienes? 'How old are you', which has not been discussed in the conversation. He then proceeds to ask her what she has done between the ages of seventeen and twenty, also with the same type of falling contour.

(4) Informant: ¿Qué has hecho en...? Cua... ¿Cuántos años tienes?

Interviewer: Veinte.

Informant: ¡Veinte años! ...De los diecisiete a los veinte, ¿qué has hecho?

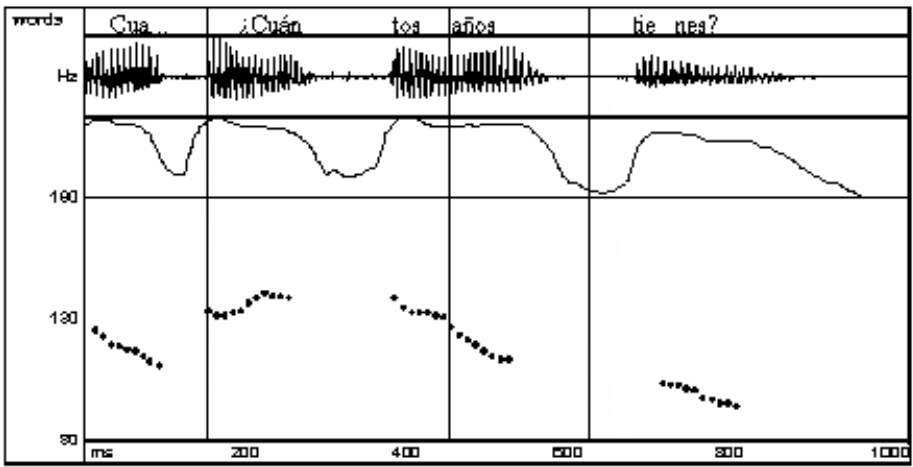

Figure 7. Wh-question with a falling contour uttered by the Mexican young male Speaker in natural speech. 
The forty-five year old Colombian female speaker had a majority of falling wh-questions in her interview, and the only rising contours were of the higher rising type, that is, not the polite, mitigated ones referred to by Navarro (1968) and shown in Figures 5 and 6 . In fact, none of her rising contours were of this type. In (5) and in Figure 8 one of her descending contours is shown (see Figure 3 above for an illustration of an emphatic, exclamatory wh-question uttered by the same subject). The speaker introduces a new topic, asking about the interviewer's ability in English: Y el inglés, ¿cómo le ha ido? 'And the English, how has it been for you?'. At this point the interviewer was saying she had to take some extra courses in Canada before entering the university.

(5) Interviewer: ...Tuve que hacer materias para revalidar mis estudios aquí en Canadá, antes de entrar a la universidad.

Informant: Y el inglés, ¿cómo le ha ido?

Interviewer: Muy bien.

Informant: ¿Bien?

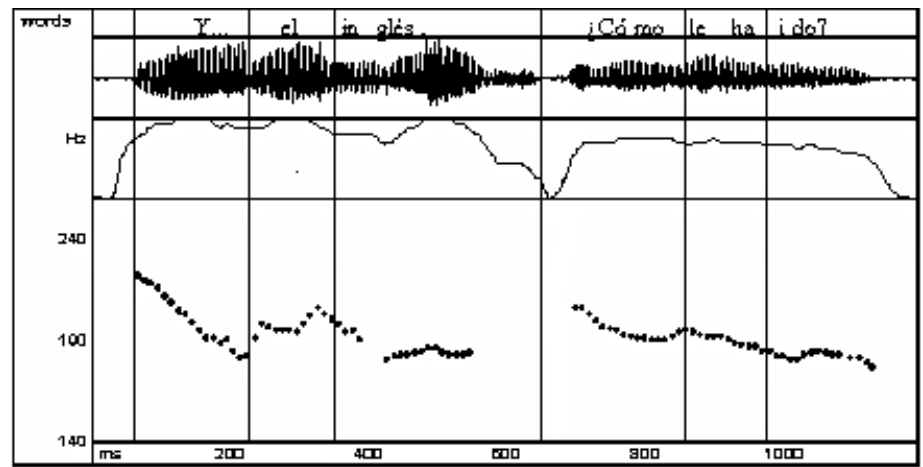

Figure 8. Falling wh-question uttered by the Colombian female speaker, natural speech.

This speaker does make use of rising contours, but as said before none of them implies politeness or mitigation, they function like reminder or reprise questions, something like «tell me again something you may have already told me», which shows that some accommodation between the speakers is going on. In (6), the topic, the background knowledge that they share a common «latino» identity is activated, and the subject requests further clarification on what is already presupposed by using the high rising contour shown in Figure 9, where the informant asks the interviewer where is she from ( $¿$ De dónde es usted?). 
(6) Interviewer: ...porque muchos latinos al venirse para Canada se encuentran aislados...

Informant: ¿De dónde es usted?

Interviewer: De Venezuela

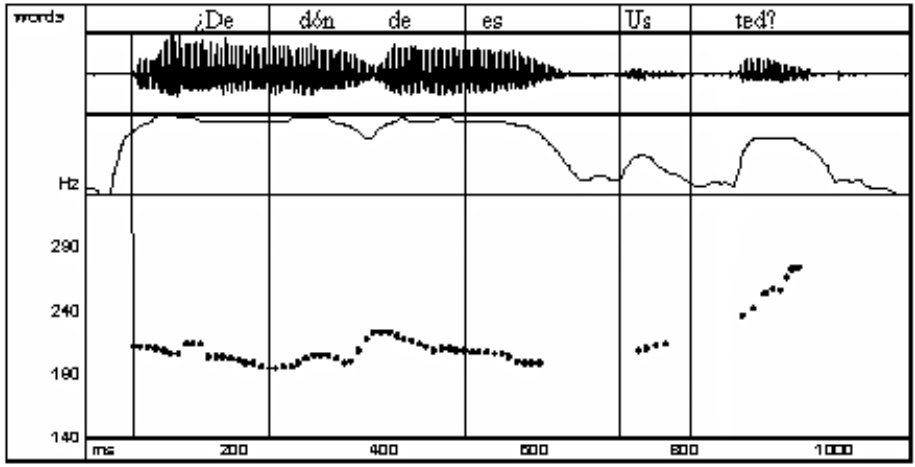

Figure 9. Higher rising contour in a reminder question, Colombian female speaker.

Although at first sight the shape may be reminiscent of Navarro's polite rising question, these contours start higher and stay high, without any particular tonal emphasis on the wh-word or locus of interrogation, which for this type of reprise wh-question does not associate with the most important rise or peak.

The Puerto Rican female subject also had the same dichotomy of falling versus rising contours, in a manner analogous to the Colombian speaker. The descending contours are straight questions, expecting new information as the answer, while the ascending ones are reprise questions, in which the speaker already has some knowledge about what she's asking and reiterates the question for further clarification. In (7) the informant asks how long the interviewer has lived in Canada (¿Desde hace cuánto estás allá en Canadá?), when the conversation was about something unrelated to the question. The contour is the standard falling one, shown in Figure 10.

(7) Interviewer: ...y salir mucho de noche puede ser cansón cuando uno anda soltero.

Informant: Y también costoso. Y... ¿Desde hace cuánto estás allá en Canadá? Interviewer: Desde el ochenta y nueve.

The contour in Figure 10 has the focus as well as the highest peak on the wh-word cuánto, 'how long' as expected in a question that asks for new information, and the fundamental frequency descends to close to the bottom of her range. 


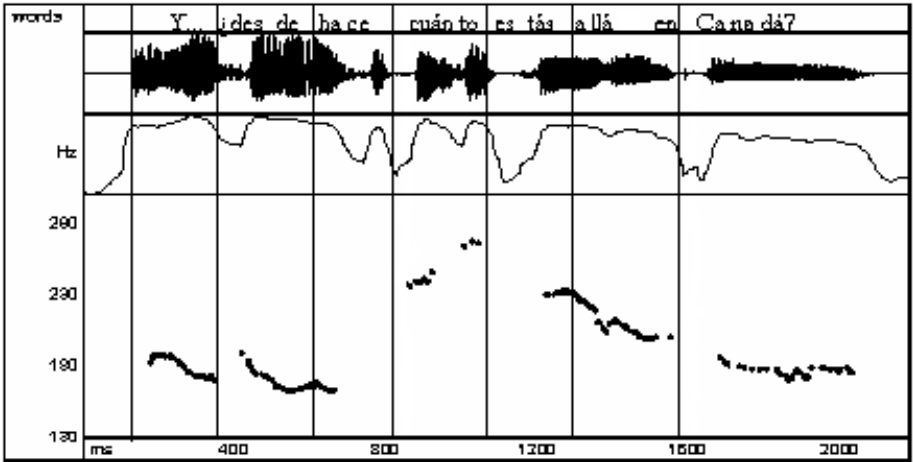

Figure 10. Falling wh-question with the highest peak on the wh-word, Puerto Rican female speaker.

All the rising wh-questions for this subject were also of the reprise type, in which the speaker requests to be reminded of something that is a presupposition or background knowledge, or has already been mentioned. In the example in (8), the speaker already knows that the interviewer arrived to Puerto Rico from Canada; the interviewer was saying that his flight was late and only arrived at 3:30 am, and the subject made a comment about how horrible that must have been, which the interviewer contradicted by saying it wasn't too bad since he stayed in the airport. She then asks how was it that the interviewer ended up in Canada ( $\dot{Y}$ cómo paraste en Canadá?), with a rising contour presented in Figure 11.

(8) Interviewer: ...y mi vuelo llegó a las tres y media de la mañana Informant: Horrible, horrible.

Interviewer: No, no fue horrible porque me quedé en el aeropuerto Informant: ¿Y cómo paraste en Canadá?

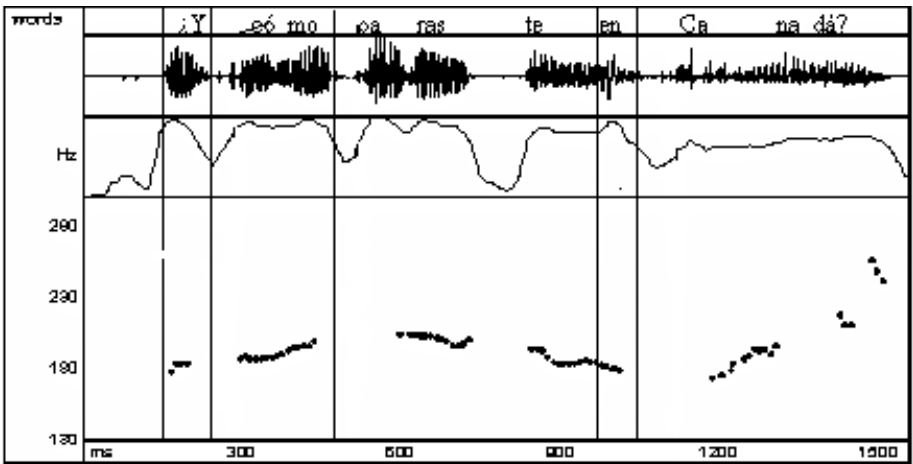

Figure 11. Rising contour in a reprise wh-question, Puerto Rican female speaker. 
The whole contour in Figure 11 is comparatively high and the wh-word is not emphasized. The overall high pitch and final rise (somehow obscured because of creaky voice) indicates that the informant is asking to be reminded of something already discussed, although not immediately present in the discourse.

The Venezuelan informant also uses both falling and rising contours, and like the others, distinguishes between the two kinds according to whether or not she expects to be informed about something she does not know, or is asking to be reminded of something she knows or thinks she should know, either implied or explicit. In the example (9) the interviewer is telling the female subject that he expects her to ask him questions, to which she responds that they have already talked about the kind of food the interviewer can cook, and asks somewhat tongue in cheek how many times a day does the interviewer take a shower there in Maracaibo (a very hot place). As can be seen in Figure 12, the contour is rather flat and falling, with the highest peak on the wh-word Cuántas 'how many.'

(9) Interviewer: ...que me hagan a mí preguntas.

Informant: A ver, qué más. Ya me habló del tipo de comida que sabe hacer... ¿Cuántas veces se baña al dia? Aquí en Maracaibo.

Interviewer: En Maracaibo, fíjate, ayer...

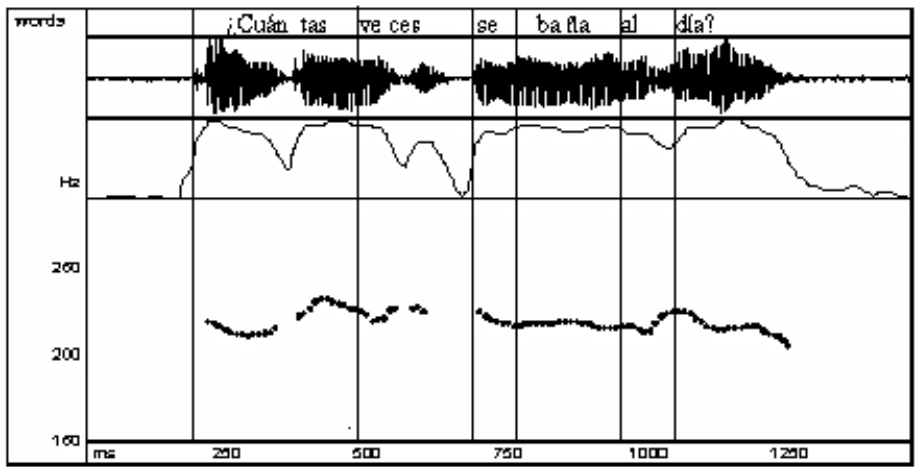

Figure 12. Falling wh-question, Venezuelan female speaker.

The rising contours of this speaker also respond to a desire to be reminded of something already in the conversational background or that is kind of obvious, in this case the age of the interviewer. In (10) the interviewer is again requesting the informant to ask him questions, and the subject then asks him about his precise age ¿Qué edad tiene usted? 'How old are you?'. In Figure 13 the rising shape of this question is shown. 
(10) Interviewer: Bueno, ¿por qué no me haces preguntas a mí ahora?

Informant: Ah bueno. ¿Qué edad tiene usted?

Interviewer: Cuarenta y seis años

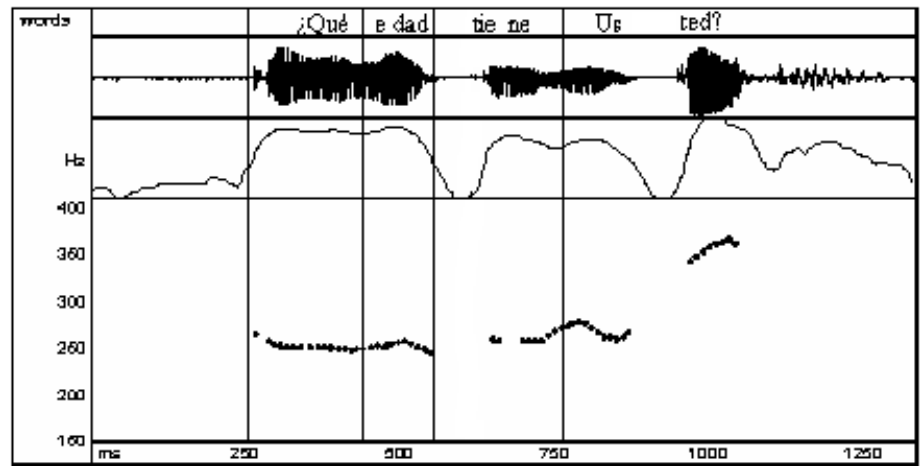

Figure 13. Rising contour in a reminder wh-question, Venezuelan female speaker.

The most revealing observation is that in sharp contrast with the kinds of rising configurations found in the questionnaire responses, none of the speakers in this corpus of unscripted speech used the polite, mitigated rising contour described by Navarro (1968) and shown in Figures 1, 5 and 6. This suggests that at least for the kind of research that tries to infer the meanings of the questions in terms of the possible answers expected by the speaker, the reading of isolated utterances by the subjects is not a reliable method. Although dialect differences in the shape and frequency of use of the variants may be identified in such laboratory conditions, it is not possible to draw reliable conclusions without first analyzing them in data-driven research of real speech.

\section{Configurations, meaning and information structure}

The obvious question that needs to be answered is why is it that the same speaker will use both falling and rising contours, and what does this mean. Given the contexts of the contours described above, it is safe to assert that they are not used for the same effects or with the same expectations from the point of view of the speaker, that is, in terms of the kinds of answer he/she wants or is likely to receive.

In these terms, that of the expected answer, there are two main types of questions: (i) those that ask for new, unknown information, and (ii) those that ask for confirmation or ratification of something that is assumed to be already mutually known, or implied in the context or background. To illustrate this distinction, in (11) the statement Pepe tiene otra amiga 'Pepe has another friend' is given, fol- 
lowed by the wh-question uttered as a response by an eventual interlocutor, ¿Quién? 'Who?' consisting of just the wh-word. The interesting issue is that this question can be uttered with any one of the four rising and falling contours described, each one of them being a possible response from the interlocutor to the previous statement.

(11) $\mathrm{Pe}$
¿Quién?
'Pepe has another friend.' 'Who?'

If this question is pronounced with the unmarked falling intonation, as in the first of Navarro's examples on Figure 1 (or in Figures 2, 7, 8, 10), then the declarative answer has to be something like «Ana» or any other member of set of possible entities such as $\{$ Ana, Marta, Josefa... $\}$, that is, information that is not known by the speaker. In (12) and in Figure 14 a real life question of this type is presented, uttered by the Puerto Rican speaker while on the phone with her daughter, who had just informed her that her younger brother was going out with a friend that afternoon. The speaker then asks her daughter ¿Con quién? 'with whom?', which is something she does not know at that point. Notice that the shape of this very short utterance in which the wh-word is the nucleus, is identical to that of the longer falling wh-questions of this pragmatic type.

(12) Informant: Um hum...

Her daughter, over the phone: [Inaudible]

Informant: ¿Con quién?

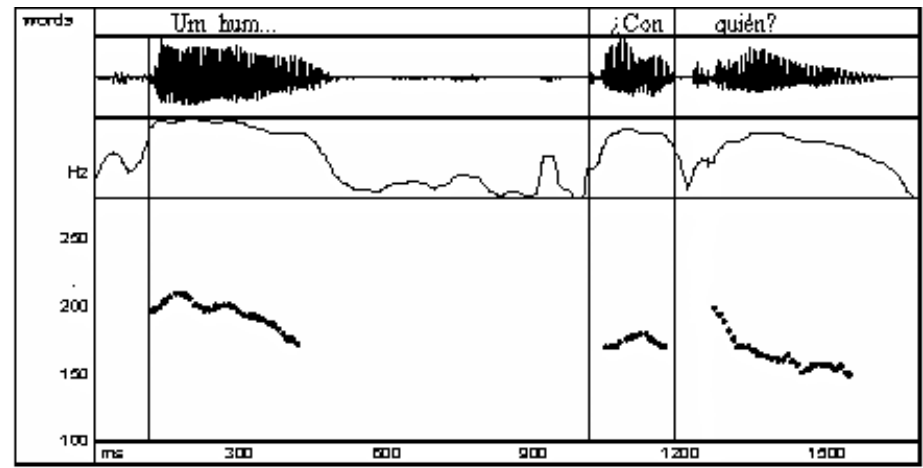

Figure 14. The wh-question ¿Con quién? uttered by the Puerto Rican speaker, talking over the phone with her daughter.

If instead of this unmarked falling contour the question has a falling-rising intonation like the one in the second of Navarro's examples in Figure 1 (or in Figures 
5 and 6), again the answer has to be something like «Ana», which would be new information for the speaker, although she or he would be expressing less commitment or urgency in knowing who is Pepe's new friend.

The answer to the question with a final rising-falling contour as in the third of Navarro's examples in Figure 1 (or in Figure 3), would also be «Ana», but the implication that triggers and characterizes it is of some surprise or amazement that Pepe could have a new friend. It is again a request directed to the hearer to supply some additional information the speaker does not have.

On the other hand and in sharp contrast with the previous contours, if ¿Quién? is uttered with a high-rising intonation, as in the examples on Figures 4, 9,11 and 13 , then the answer has to be «Pepe», that happens to have been just mentioned. So, no new information is the purpose of this question since the topic already relates to Pepe. This type of question requests confirmation of given or old information, thus relates to a third category of meaning associated with these sentences, information structure meaning. In this last type of rising wh-question, the wh-word is never the highest peak of the contour, which on the contrary is nearly always the case in all three configurations described by Navarro (1968: 229), and also in those described by Quilis (1993). So, in addition to the difference in the kind of answer expected, there is a regular difference in configuration as well, that affects the tonal prominence of the wh-word or locus of interrogation in the utterance.

For all the informants the overwhelming majority of configurations were falling contours in the dialogues, which is consistent with the findings of Hirschberg (2000) for English in a corpus-based study. In her data only $8 \%$ or $9 \%$ of the wh-questions were uttered with final rise. Of course we cannot equate the significance of these results with our Spanish data because we are dealing with different languages. However, her results do show differences in final contours in read vs. spontaneous speech, which at least for our Mexican and Colombian subjects also seemed relevant.

\section{Conclusion}

The results reported here point to a conclusion regarding the tonal structure of whquestions in Spanish in general, which is that the default or unmarked configuration is indeed the gradually descending one, as described in the traditional literature and notably by Navarro (1968) and Quilis (1993). This applies to all the dialects here examined, in spite of the variable use of the encountered contours. A finding that is not unexpected is that this variability is context-induced, that is, wh-questions are structurally oriented toward the specific kind of answer that is expected from the addressee, according to what has been said or implied before in the conversation.

Wh-questions do not ask for a truth value like the yes-no interrogatives do, instead they can have very many possible answers. The sole presence of the whword is not enough to specify the expected nature of the reply and for that reason the intonational profile of the utterance is crucial. Although the wh-word itself is normally distinctly marked with high pitch, whether or not it is associated with the highest peak in longer utterances is, as we saw, an indicator of which possible answers are allowed. 
Regarding the neutral or unmarked configurations for the different dialects, the data remains inconclusive: whereas the responses to the questionnaire pointed to two kinds of preferred structure, the interviews produced results that were in themselves rather coherent and regular and following the existing accounts of the configurations of wh-questions.

The difference in use of rising vs. falling wh-questions in read and naturallyoccurring speech was of no significance for the speakers of Caribbean Spanish. For the Mexicans and Colombians the results were very different between read and naturally-occurring wh-questions. However, the data here examined turned out to be too restricted to observe real differences in this respect.

To conclude, this study stresses the fact that for this kind of research on natural speech, a corpus consisting of sufficient speakers per dialect (maybe more than those I have considered here), and different contexts, is a necessity. Also, that read or laboratory speech tends to be unreliable since they fail to take into consideration the context, thus making the generation of real communicative and interactional meanings a very elusive task. Other dimensions such as the familiarity and status of the participants, the communicative situation and the kinds of effects the speaker intends to have on the hearer(s) are also crucial in the study of the correlations between prosodic structure and meaning.

\section{References}

D’Introno, Francesco; Sosa, Juan M. (1986). La pronunciación del español. Curso práctico. University of Massachusetts, unpublished manuscript.

Hedberg, Nancy; Sosa, Juan M. (2002). «The prosody of questions in Natural discourse». Proceedings of Speech Prosody 2002, Aix-en-Provence, pp. 375-378.

Hirschberg, Julia (2000). «A corpus-based approach to the study of speaking styles». In: Horne, M. (ed). Prosody:Theory and Experiment. Dordrecht: Kluwer, pp. 335350.

Navarro Tomás, Tomás (1944). Manual de entonación española. New York: Hispanic Institute in the United States.

- (1968). Manual de pronunciación española. Madrid: CSIC.

Quilis, Antonio (1993). Tratado de fonología y fonética españolas. Madrid: Gredos. Sosa, Juan M. (1999). La entonación del español. Madrid: Cátedra. 